\title{
Seasonal stocking of tobosa managed under continuous and rotation grazing
}

\author{
D.M. ANDERSON
}

\section{Abstract}

Tobosa (Hilaria mutica [Buckl.] Benth.) was seasonally grazed with cattle under hiph-density (2.1 to $5.1 \mathrm{animal}$ unit/hectare [AU/ha]) rotation and low-density $(0.33$ and $0.39 \mathrm{AU} / \mathrm{ha})$ continuous stocking in 1980 and 1981, respectively. Tobosa leaf and culm color were used to evaluate forage quality. At the end of the 1980-81 growing seasons, crude protein was highest in green tobosa $(8.4 \%$ ) and lowest in gray tobosa from the previous seasons (4.7\%). Graxing strategies did not influence the proportion of green tobosa within the standing crop; however, nexible rotation produced a more uniform use of green tobosa within the cell when compared to grazing with fixed intervals between rotations. Grazing patterns result from improper utilization of green tobosa which in future years will senesce into gray colored tobosa that composed 46-91\% of the standing crop. In this study, flexible rotation of cattle among paddocks, based on a 30-35\% reduction of tobosa standing crop height, reduced gray tobosa within the standing crop more than did continuous stocking. Total heifer liveweight gain per ha in 1980 and 1981, respectively, was 43 and $24 \%$ less under continuous stocking compared to rotation grazing management.

Key Words: seasonal grazing strategies, tobosa utilization, heifer average daily gain, standing crop quality

Tobosa (Hilaria muttca [Buckl.] Benth.) is an important climax grass on adobe flood plains of the arid Southwest. Low humidity and high potential evaporation rates that can exceed $300 \mathrm{~mm}$ during June, coupled with low and often erratic precipitation, complicate management of livestock grazing in this region. Tobosa should be grazed when actively growing and crude protein is highest. Crude protein in mature tobosa can drop below $5 \%$, an unacceptable nutritional level (Nelson et al. 1970). Burning, nitrogen fertilization, foliar application of molasses on mature tobosa, and haying have all been investigated as management methods to improve utilization (Herbel and Nelson 1974).

Conservative continuous stocking during the growing season, the traditional method by which tobosa has been grazed in the arid Southwest, results in nonuniform utilization with mature tobosa standing crop accumulating from year to year. If excees dead forage is allowed to accumulate, poor cattle performance may

Author is research animal scientist, USDA-ARS, Jormada Experimental Range, Las Cruces, New Mexico 88003.

This article is published cooperatively with the New Mexico Agr. Exp. Sta. as Journal Article 1207, New Mexico State University, Las Cruces.

Manuscript accepted 29 June 1987. result, along with retarded plant growth (Kucera and Ehrenreich 1962, Beaty et al. 1982). Conservative stocking and slow rates of plant decomposition are 2 factors that contribute to the accumulation of excess standing dead forage in arid ecosystems.

Fixed interval rotation of animals among paddocks also may not provide high quality forage for the grazing animal. Regrowth will decline in quality, as a result of senescence, if intervals of rest are excessively long. High-stock-density rotational grazing using flexible grazing intervals has been proposed as a management tool to maintain an acceptable quantity and quality of standing crop, yet maintain livestock production (Savory 1978). By producing a standing crop of uniform height, described by McNaughton (1984) as a grazing lawn, animal intake may be enhanced. However, little research on high-stock-density rotational grazing has been done under arid or semiarid conditions (Anderson 1981). The objectives of this study were to manage tobosa under high-density rotation and low-density continuous grazing on a seasonal basis and evaluate: 1) standing crop quantity (kg/ha), 2) crude protein (\%) content for several color (maturity) classes of tobosa standing crop at the end of the growing season, and 3) heifer liveweight gains.

\section{Materials and Methods}

The study site was located on the Jornada Experimental Range ( $106^{\circ} 44^{\prime} \mathrm{W}, 32^{\circ} 29 \mathrm{~N}$ ) in Dona Ana County near Las Cruces, New Mexico at an elevation of $1,280 \mathrm{~m}$ above sea level. The vegetation is essentially a pure stand of tobosa interspersed with patches of burrograss (Scleropogon brevifolius Phil.) with a scattered overstory of tarbush (Flourensia cernua DC.) and soaptree yucca (Yucca elata Engelm.). With adequate precipitation, numerous annual and perennial forbs also occupy this essentially level ( $\leq .04 \%$ slope), clayey, bottomland site.

The climate is characterized by abundant sunshine coupled with wide diurnal variation in ambient air temperatures. Daily maximum temperatures average $36^{\circ} \mathrm{C}$ in June and $13^{\circ} \mathrm{C}$ in January. About $52 \%$ of the $230 \mathrm{~mm}$ average annual precipitation originates from highly localized, short duration, intense, convective thunderstorms that occur between 1 July and 30 September (Paulsen and Ares 1962).

The study involved 3 treatments: 2 grazing treatments and a no-graze control. The 2 areas grazed were separated by approximately $0.8 \mathrm{~km}$. Low-density ( .33 to $.38 \mathrm{au} / \mathrm{ha}$ ) continuous stocking was conducted in a 33.6-ha paddock while a 34.7-ha cell, subdi- 
vided into 10 smaller paddocks, was managed under high density (2.0 to $5.7 \mathrm{au} / \mathrm{ha}$ ) stocking (Fig. 1). Plots excluded from cattle grazing were located in a paddock which lay between the 2 grazed areas.

Mature cows and 6-to-18-month old heifers were grazed in 1980 and heifers only in 1981 (Table 1), but only heifer liveweight change

Table 1. Comparison of continuous and rotation graxing of toboan in 1980 and 1981.

\begin{tabular}{|c|c|c|c|c|}
\hline \multirow{2}{*}{$\frac{\text { Category }}{\text { General }}$} & \multicolumn{2}{|c|}{1980} & \multicolumn{2}{|c|}{1981} \\
\hline & Continuous & Rotation & Continuous & Rotation \\
\hline Study dates & \multicolumn{2}{|c|}{ May 21 to Nov. 5 (168 d) } & \multicolumn{2}{|c|}{ July 14 to Oct. 29 (107 d) } \\
\hline $\begin{array}{l}\text { Number of } \\
\text { paddocks }\end{array}$ & & 10 & & 10 \\
\hline $\begin{array}{l}\text { Mean paddock } \\
\text { size (ha) }\end{array}$ & 33.6 & 2.9 to 5.8 & 33.6 & 2.9 to 5.8 \\
\hline $\begin{array}{l}\text { Rotation } \\
\text { schedule }\end{array}$ & \multicolumn{2}{|c|}{ Fixed calendar dates } & \multicolumn{2}{|c|}{$\begin{array}{l}\text { Standing crop } \\
\text { disappearance }\end{array}$} \\
\hline \multicolumn{5}{|c|}{ Grazing (days/cycle) } \\
\hline $\begin{array}{l}\text { Mean } \\
\text { Range }\end{array}$ & & $\begin{array}{c}4.1 \\
1.3 \text { to } 7.7\end{array}$ & & $\begin{array}{c}3.1 \\
1.0 \text { to } 9.0\end{array}$ \\
\hline \multicolumn{5}{|c|}{ Resting (days/cycle) } \\
\hline $\begin{array}{l}\text { Mean } \\
\text { Range }\end{array}$ & & $\begin{array}{c}37.6 \\
32.3 \text { to } 40.2\end{array}$ & & $\begin{array}{c}27.7 \\
19.2 \text { to } 38.0\end{array}$ \\
\hline \multicolumn{5}{|l|}{ Livestock } \\
\hline Number & 13 & 15 & 24 & 27 \\
\hline Breed1 & \multicolumn{2}{|c|}{$\underset{\text { HxB }}{H, B, ~ S G x H, ~ B x H, ~ B x S G, ~}$} & \multicolumn{2}{|c|}{$\mathrm{H}$ and $\mathrm{B}$} \\
\hline \multicolumn{5}{|c|}{ - -5} \\
\hline Number & 4 & 4 & & \\
\hline Breed 1 & & & & \\
\hline \multicolumn{5}{|c|}{ Mean seasonal stocking } \\
\hline Rate (AUD/hs & a) 53 & 58 & 41 & 44 \\
\hline $\begin{array}{l}\text { Density } \\
\text { (AU/ha) }\end{array}$ & 0.33 & 2.0 to 4.7 & 0.38 & 2.4 to 5.7 \\
\hline
\end{tabular}

'H $=$ Hereford, $B=$ Brangus, SG = Santa Gertrudis, SG $/ \mathbf{H}=$ SGxH and HxSG.

was used to evaluate animal performance in both years, as cow numbers in 1980 were two small for acceptable estimates of gains. The cattle were provided ad libitum access to both trace mineral blocks and water in the corral areas shown in Figure 1.

All liveweights were obtained after the livestock had been held overnight in a drylot without feed or water. All cattle were weighed immediately before initiating grazing and at the end of each grazing cycle in 1980 and 1981 . A cycle was defined as the total grazing time on all padd ocks within the cell before the herd was returned to the paddock originally grazed. Length and beginning dates of the cycles, stocking rate, stocking density, and the basis on which the livestock were rotated within the cell differed between 1980 and 1981 (Tables 1 and 2).

The single herd of cattle was rotated through the 10-paddock cell sequentially in a counter-clockwise direction in both 1980 and 1981. During 1980, the triangular paddocks 1 thru 3, 5 thru 8, and 10 each were grazed for 3 or 4 days each cycle, and the 2 larger paddocks, 4 and 9, were grazed for approximately 7 days each. Rotation schedules in each of the cycles through the 10-paddock cell in 1981 were kept flexible to match standing crop growth with forage demand. The 10 paddocks within the rotation cell were monitored as each was being grazed. On the day preceding grazing, and each day while the heifers were grazing the paddock, visual estimates of standing crop height were made at a minimum of 10 locations in the paddock. When grazing had reduced the average standing crop height by 30-35\% from that estimated initially, cattle were moved to the adjacent fresh paddock (Toloumbaye 1982).

Grazing in 1981 was begun in paddock 9 of the cell to remove abundant mature standing crop early in the season. Paddocks 9 , 10 , and 1 each contained in excess of $1,000 \mathrm{~kg} / \mathrm{ha}$ standing crop when the end-of-season clipping was done in November 1980. Three grazing cycles were completed in 1981 while only paddocks 1,9 , and 10 were grazed for a fourth time before grazing was terminated because of inadequate standing crop in the 7 remaining paddocks of the cell.

Immediately after the first killing frost in 1980 and 1981 , standing crop from each plot was hand clipped to ground level and bagged. The plants to be clipped were delineated within $0.3 \times$ 1.5-m steel frames which were located in a random fashion within each area sampled. The number of frames clipped at each plot location varied with the density of the standing crop; 4 to 12 frames were needed to provide enough forage for later analysis.

Plots within the continuous grazing treatment were randomly located throughout the $33.6 \mathrm{ha}$. Within the cell 2 plots were clipped in each of the 10 paddocks. By clipping 2 plots per paddock, within paddock variability could be estimated. One plot was within $100 \mathrm{~m}$ of the water source and the second was within $100 \mathrm{~m}$ of the perimeter fence farthest from the water source. In 1980, 18 plots were clipped in the continous grazing treatment and 20 plots were clipped in the 10-paddock cell. In 1981, 20 plots were clipped in both treatments. Four plots were clipped in the no-graze control both years.

Samples of tobosa from each clipped plot were taken. Each sample was separated into 3 color categories: (1) green biomass; (2) brown biomass, current year's green production which had senesced prior to clipping; and (3) gray biomass, forage produced prior to the current year's growth. Weights for each category were

Table 2. Precipitation' $(\mathrm{mm})$ received during four graxing cycles for the years 1990 and 1981 and departures from long-term yearly averages in a continuoualy stocked paddock and a 10-paddock cell located on the Jornada Experimental Range.

Precipitation, mm

\begin{tabular}{|c|c|c|c|c|c|c|c|}
\hline & \multicolumn{7}{|c|}{ Precipitation, mm } \\
\hline & \multicolumn{5}{|c|}{ Cycles } & & \\
\hline & $\begin{array}{c}1 \\
\text { (21 May - } 2 \\
\text { July 1980: } \\
\text { 14 Jul - 11 } \\
\text { Aug 1981) }\end{array}$ & $\begin{array}{c}2 \\
\text { (2 Jul - 15 } \\
\text { Aug 1980: } \\
11 \text { Aug- } 12 \\
\text { Sept 1981 }\end{array}$ & $\begin{array}{c}3 \\
\text { (15 Aug - 24 } \\
\text { Sep 1980: } \\
\text { 12 Sep - 13 } \\
\text { Oct 1981) }\end{array}$ & $\begin{array}{c}4 \\
\text { (24 Sep - } 5 \\
\text { Nov 1980: } \\
13 \text { Oct - 29 } \\
\text { Oct 1981) }\end{array}$ & Total & \multicolumn{2}{|c|}{ Year } \\
\hline & & & & & & Received & Departure \\
\hline $\begin{array}{l}1980 \\
\text { Continuous } \\
\text { Rotation }\end{array}$ & $\begin{array}{l}0 \\
1\end{array}$ & $\begin{array}{l}42 \\
14\end{array}$ & $\begin{array}{l}53 \\
42\end{array}$ & $\begin{array}{l}12 \\
23\end{array}$ & $\begin{array}{r}107 \\
80\end{array}$ & $\begin{array}{l}207 \\
152\end{array}$ & $\begin{array}{l}-23 \\
-78\end{array}$ \\
\hline $\begin{array}{l}1981 \\
\text { Continuous } \\
\text { Rotation }\end{array}$ & $\begin{array}{l}31 \\
69\end{array}$ & $\begin{array}{l}85 \\
52\end{array}$ & $\begin{array}{r}17 \\
1\end{array}$ & $\begin{array}{r}11 \\
1\end{array}$ & $\begin{array}{l}144 \\
123\end{array}$ & $\begin{array}{l}238 \\
220\end{array}$ & $\begin{array}{l}+8 \\
-10\end{array}$ \\
\hline
\end{tabular}

'A standard rain gauge was located in the southeast corner of the continuously stocked paddock while a recording rain gauge was located near the ten-paddock cell. 
TEN PADDOCK CELL

Fom

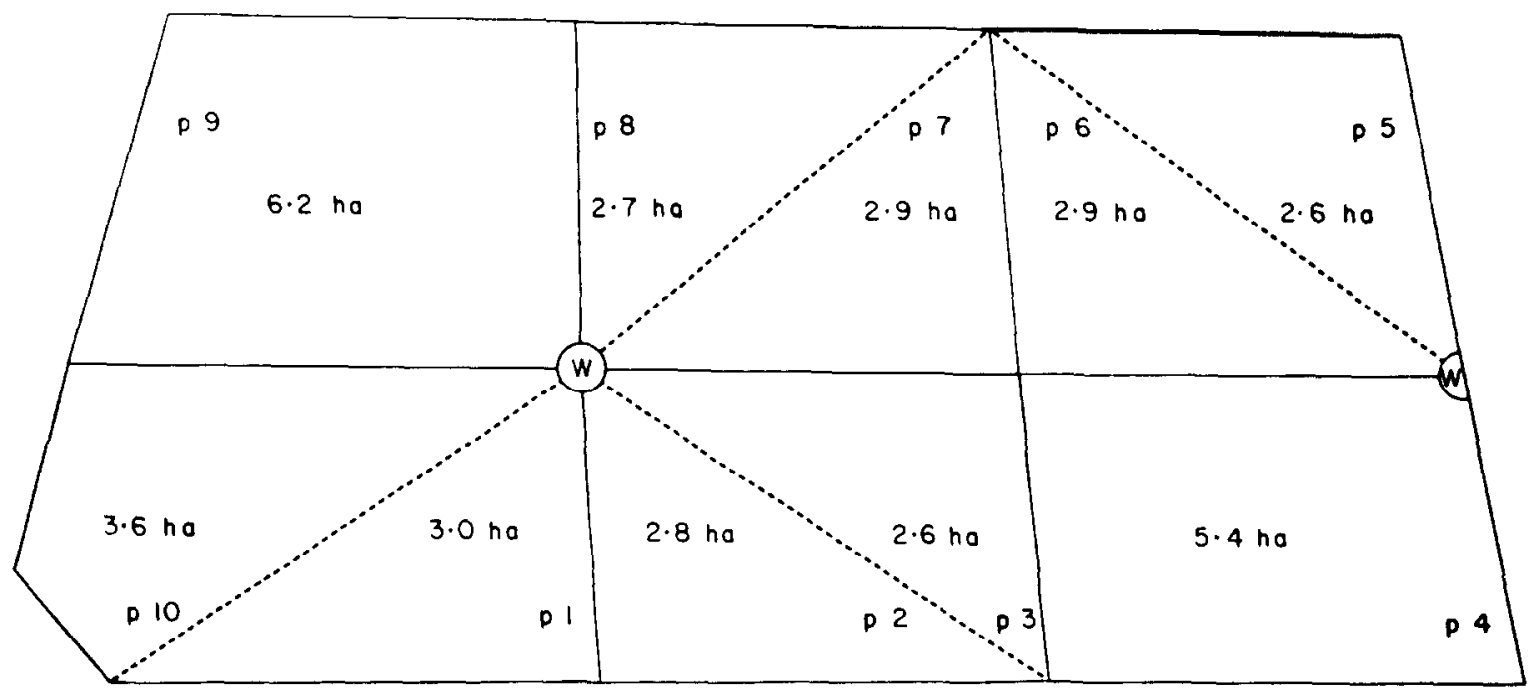

SOUTH CONTINUOUS PADDOCK

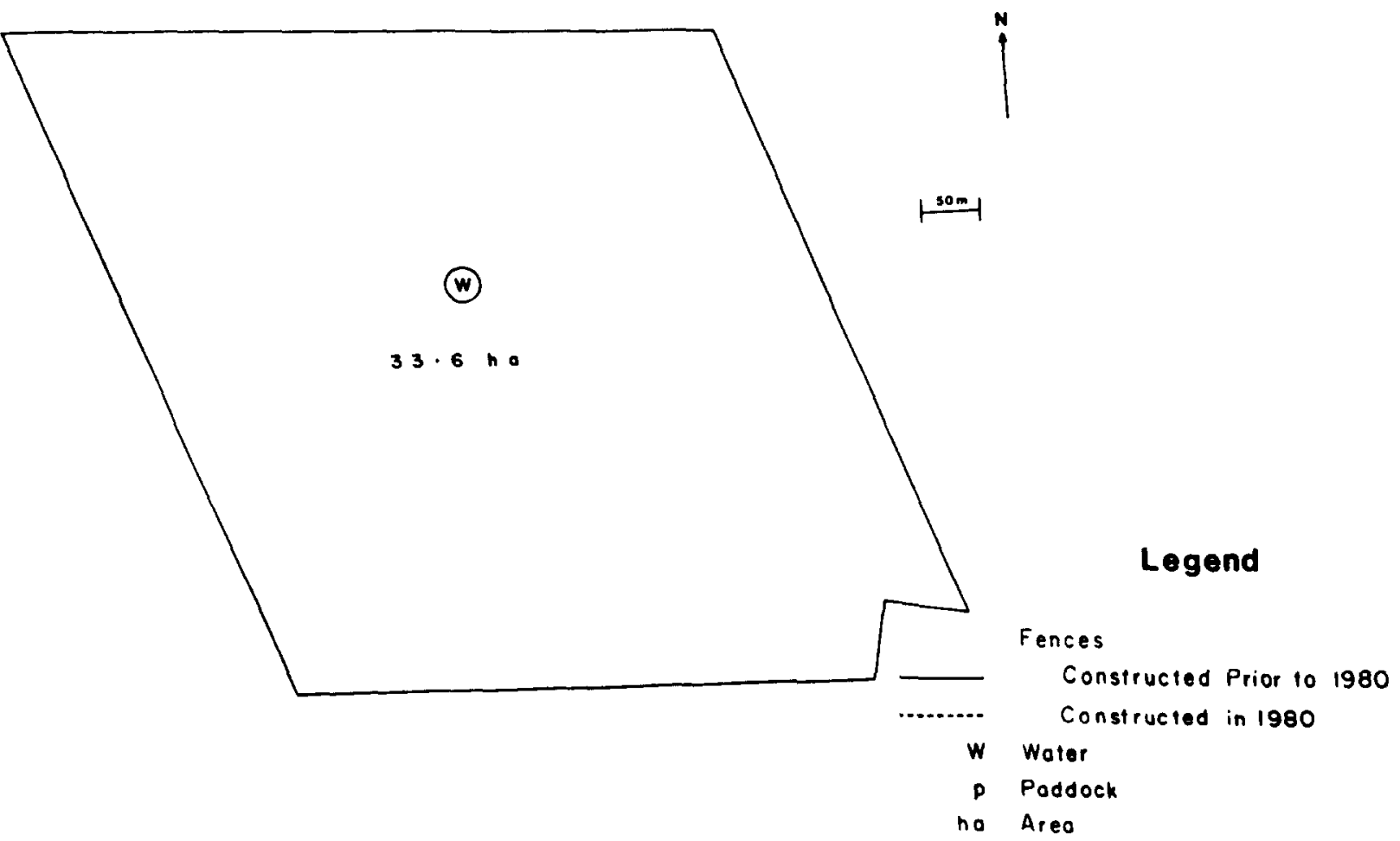

Fie. 1. Shape of a 34.7 ha 10-paddock cell and a 33.6 ha paddock with water locations inside corrals. 
Table 3. Least square mean plua a minus standard errors for composite, green, brown, and gray colored tobose and other standing crop (kg/ha) which includes miscellaneous grasses and forbs obtained from plots clipped after the first klling frost in 1930 and 1981 within a continuously stocked paddock, a 10-paddock cell, and a no-zraze control located on the Jornada Experimental Range.

\begin{tabular}{|c|c|c|c|c|c|c|c|c|c|c|}
\hline \multirow[b]{3}{*}{ Paddock } & \multicolumn{10}{|c|}{ Component ${ }^{\prime}$} \\
\hline & \multicolumn{2}{|c|}{ Total } & \multicolumn{2}{|c|}{ Green tobosa } & \multicolumn{2}{|c|}{ Brown tobosa } & \multicolumn{2}{|c|}{ Gray tobosa } & \multicolumn{2}{|c|}{ Other } \\
\hline & 1980 & 1981 & 1980 & 1981 & 1980 & 1981 & 1980 & 1981 & 1980 & 1981 \\
\hline $\begin{array}{l}\text { Continuous } \\
\text { Cell } \\
\text { Control }\end{array}$ & $\begin{array}{r}833^{b} \pm 225 \\
832^{b} \pm 207 \\
2,039^{a} \pm 463\end{array}$ & $\begin{array}{r}1,109^{b} \pm 78 \\
711^{c} \pm 78 \\
2,096^{a} \pm 174\end{array}$ & $\begin{array}{r}49^{b} \pm 20 \\
62^{b} \pm 19 \\
257^{a} \pm 42\end{array}$ & $\begin{array}{l}157^{a b} \pm 19 \\
122^{b c} \pm 19 \\
232^{a} \pm 43\end{array}$ & $\begin{array}{l}29^{b} \pm 6 \\
19^{b} \pm 5 \\
47^{a} \pm 12\end{array}$ & $\begin{array}{l}442^{a} \pm 38 \\
220^{b} \pm 38 \\
512^{a} \pm 85\end{array}$ & $\begin{array}{r}750^{b} \pm 201 \\
740^{b} \pm 185 \\
1,700^{\mathrm{a}} \pm 414\end{array}$ & $\begin{array}{r}510^{b} \pm 48 \\
363^{\mathrm{c}} \pm 48 \\
1,345^{\mathrm{a}} \pm 108\end{array}$ & $\begin{array}{l}11^{b} \pm 4 \\
12^{b} \pm 3 \\
35^{a} \pm 7\end{array}$ & $\begin{array}{r}11^{*} \pm 2 \\
6^{a} \pm 2 \\
8^{a} \pm 4\end{array}$ \\
\hline
\end{tabular}

The five components are defined as follows:

Total - forage as clipped and not separated into species and tobosa color components.

Green tobosa - produced during the current year.

Brown tobosa - produced during the current year but senesced.

Gray tobosa - produced prior to the current year.

Other - grasses and forbs other than tobosa.

Means in the same column with the same superscript are not different $(P>.05)$ according to the Proc GLM and SAS procedure.

recorded separately. The 3 color categories along with a total sample not separated into color components were composited across locations within pastures and ground to pass a $0.5-\mathrm{mm}$ screen in preparation for chemical analysis. Nitrogen concentration (dry matter basis) was determined, using the Kjeldahl procedure (AOAC 1970), and dry matter and ash contents of each color category and the total were determined.

Vegetation data were analyzed in a completely random design for each year separately using the General Linear Model (GLM) in the Statistical Analysis System (SAS 1979). Standing crop was analyzed by locations within treatments, but chemical data were analyzed by treatment since plant material from all plots was composited within each year prior to chemical analysis. Analysis of the chemical data required calculation of a common error term from the three way interaction of paddock with years and color. Therefore, the chemical analyses of plant material based on main effects provide only a preliminary indication of the forage quality. The 1980 and 1981 liveweight and ADG data were analyzed separately by year in a completely random design with a 2 factor factorial (grazing treatment $X$ breed) on the whole plot and grazing cycle on the split plot. Unless otherwise stated, if $F$ values were significant $(P \leq .05)$, least squares means and standard errors were separated according to the Proc GLM and SAS procedures at $P \leq .05$.

\section{Results and Discussion}

The total and temporal distribution of precipitation varied within and between years (Table 2) during this 2-year study; 1980 was approximately $20 \%$ drier than 1981 . Of the precipitation that did occur during the study, $69 \%$ of the precipitation events in 1980 were recorded during September-October, compared to $67 \%$ during July-August 1981 . The precipitation events that could have influenced growth were reduced from $69 \%$ to $56 \%$ for the September-October period in 1980 because the first killing frost was recorded during the last half of October. The spatial pattern of precipitation also varied. In both years, more precipitation was received within the continuously stocked paddock than within the cell.

\section{Standing Crop-Quantity}

Differences among standing crop on the 3 treatments at the end of the 1980 growing season only approached significance for a total $(P=.0592)$, brown tobosa $(P=.0915)$, and gray tobosa $(P=.1045)$, while the category grasses other than tobosa, and forbs was significant $(P<.05)$. The difference in green tobosa was highly significant $(P<.0005)$ among the treatments (Table 3). The ungrazed control contained more than 4 and 5 times more green tobosa than the rotationally grazed cell and continuously stocked paddocks, respectively. The control contained more tobosa standing crop in 1980 than did either grazing treatment, regardless of component. In 1981 , the 3 treatments differed in total $(P<.0001)$ and gray $(P<.0001)$ tobosa standing crop in the order control $>$ continuous $>$ cell. Green only approached significance $(P=.0671)$ while the category grasses and forbs other than tobosa was not significant $(P>.05)$. Brown tobosa also differed $(P<.0005)$ among the 3 treatments in 1981; the amount of brown tobosa in the control and continuously stocked paddock was more than twice that found in the cell (Table 3). As in 1980, there was more tobosa standing crop in the ungrazed control than in either grazing treatment (Table 3). The ungrazed control and continuously stocked paddock contained similar amounts of green tobosa; however, the control contained approximately twice the amour: of green tobosa than the rotationally grazed cell.

Table 4. Least square means plus and minus standard errors for the composite, green, and gray colored tobosa standing crop (kg/ha), obtained from clippling two plots in each paddock of a 10-paddock cell after the first killing frost in 1980 and 1981 on the Jomada Exy sriment Range.

\begin{tabular}{|c|c|c|c|c|c|c|}
\hline \multirow[b]{3}{*}{ Paddock } & \multicolumn{6}{|l|}{ Component } \\
\hline & \multicolumn{2}{|c|}{ Total } & \multicolumn{2}{|c|}{ Green tobosa } & \multicolumn{2}{|c|}{ Gray tobosa } \\
\hline & 1980 & 1981 & 1980 & 1981 & 1980 & 1981 \\
\hline $\begin{array}{r}1 \\
2 \\
3 \\
4 \\
5 \\
6 \\
7 \\
8 \\
9 \\
10\end{array}$ & $\begin{array}{r}1,784^{\text {ab }} \pm 370 \\
406^{\text {ed }} \pm 20 \\
465^{\text {ed }} \pm 168 \\
157^{d} \pm 3 \\
829^{\text {cd }} \pm 353 \\
243^{d} \pm 183 \\
712^{\text {ed }} \pm 235 \\
607^{\text {ed }} \pm 54 \\
1,113^{\text {be }} \pm 3 \\
2,009^{\text {a }} \pm 418\end{array}$ & $\begin{array}{ccr}601^{\text {cd }} & \pm 95 \\
622^{\text {ed }} & \pm & 49 \\
707^{\text {abod }} \pm & 2 \\
511^{\text {d }} & \pm 134 \\
974^{\text {ab }} & \pm 25 \\
514^{\text {d }} & \pm 76 \\
1,018^{\mathrm{e}} & \pm 112 \\
603^{\text {ed }} & \pm 17 \\
891^{\text {abc }} & \pm 201 \\
669^{\text {bod }} \pm 28\end{array}$ & $\begin{array}{r}162^{\mathrm{a}} \pm 37 \\
57^{\mathrm{b}} \pm 14 \\
31^{\mathrm{b}} \pm 1 \\
19^{\mathrm{b}} \pm 5 \\
46^{\mathrm{b}} \pm 29 \\
24^{\mathrm{b}} \pm 15 \\
44^{\mathrm{b}} \pm 2 \\
52^{\mathrm{b}} \pm 2 \\
57^{\mathrm{b}} \pm 8 \\
127^{\mathrm{a}} \pm 25\end{array}$ & $\begin{array}{r}163^{a} \pm 55 \\
104^{*} \pm 30 \\
141^{*} \pm 35 \\
167^{*} \pm 134 \\
122^{a} \pm 5 \\
45^{a} \pm 10 \\
142^{a} \pm 70 \\
141^{a} \pm 26 \\
119^{a} \pm 85 \\
78^{a} \pm 1\end{array}$ & $\begin{array}{r}1,582^{\mathrm{eb}} \pm 343 \\
334^{\mathrm{dd}} \pm 2 \\
419^{\mathrm{dd}} \pm 167 \\
132^{\mathrm{d}} \pm 3 \\
733^{\mathrm{dd}} \pm 313 \\
203^{\mathrm{dd}} \pm 156 \\
649^{\mathrm{dd}} \pm 241 \\
530^{\mathrm{dd}} \pm 47 \\
1,008^{\mathrm{dc}} \pm 19 \\
1,806^{\mathrm{d}} \pm 469\end{array}$ & $\begin{array}{l}261^{\text {od }} \pm 43 \\
306^{\text {bod }} \pm 40 \\
378^{\text {abe }} \pm 43 \\
125^{\text {d }} \pm 32 \\
509^{\text {ab }} \pm 79 \\
303^{\text {bed }} \pm 9 \\
561^{\text {a }} \pm 78 \\
253^{\text {ad }} \pm 33 \\
509^{\text {ab }} \pm 79 \\
431^{\text {abe }} \pm 131\end{array}$ \\
\hline
\end{tabular}

'The three components are defined as follows:

Total - forage as clipped and not separated into species and tobosa color components.

Green tobosa - produced during the current year.

Gray tobosa - produced prior to the current year.

Means in the same column with the same superseript are not different $(P>.05)$ according to the Proc GLM and SAS procedure. 
The standing crops of total, brown, and gray tobosa were not influenced $(P>.05)$ by distance from the drinking water in either grazing treatment either year. In 1980, distance from the drinking water did not significantly $(P>.05)$ influence green tobosa standing crop in either grazing treatment. In 1981, in the cell, there was more $(P<.005)$ green tobosa $(165 \pm 19 \mathrm{~kg} / \mathrm{ha})$ at the end of the paddock farthest from the drinking water, compared to the area near the drinking water $(80 \pm 19 \mathrm{~kg} / \mathrm{ha})$. Green tobosa standing crop was not $(P>.05)$ influenced by distance from the water within the continuously stocked paddock in 1981.

Large paddocks $(4,9)$ did not differ $(P>.05)$ from small $(1$ thru 3 , 5 thru 8,10 ) in the amount of total, green, brown, or gray tobosa standing crop during either 1980 or 1981 . Total and gray tobosa standing crop differed $(P<.05)$ in 1980 and in 1981 among the 10 paddocks of the cell (Table 4). However, the flexible rotation

Table 5. Least square means and standard errors for helfer mean liveweight and mean ADG (kg/da) during 1980 and 1981 from continuous and rotational seasonal stocking of tobosa rangeland.

\begin{tabular}{|c|c|c|c|c|}
\hline \multirow[b]{2}{*}{ Cycle Dates 1} & \multicolumn{2}{|c|}{ Continuous } & \multicolumn{2}{|c|}{ Cell } \\
\hline & Liveweight & ADG & Liveweight & ADG \\
\hline $\begin{array}{l}1980 \\
\text { May } 21 \\
\text { May } 21 \text {-July } 2 \\
\text { July 2-Aug. } 15 \\
\text { Aug. 15-Sept. } 24 \\
\text { Sept. 24-Nov. } 5 \\
\text { Nov. } 5\end{array}$ & $214 \pm 2$ & $\begin{array}{r}0.67^{\mathrm{a}} \pm 0.07 \\
-0.03^{\mathrm{b}} \pm 0.07 \\
0.11^{\mathrm{b}} \pm 0.07 \\
-0.06^{\mathrm{b}} \pm 0.07\end{array}$ & $187 \pm 4$ & $\begin{array}{r}0.37^{a} \pm 0.12 \\
0.09^{a} \pm 0.12 \\
-0.11^{b} \pm 0.12 \\
-0.05^{b} \pm 0.12\end{array}$ \\
\hline Mean & $238 \pm 1$ & $0.17 \pm 0.03$ & $200 \pm 2$ & $0.08 \pm 0.04$ \\
\hline $\begin{array}{l}1981 \\
\text { July } 14 \\
\text { July } 14-\text { Aug. } 11 \\
\text { Aug. 11-Sept. } 12 \\
\text { Sept. 12-Oct. } 13 \\
\text { Oct.13-Oct. } 29^{2} \\
\text { Oct. } 29\end{array}$ & $228 \pm 2$ & $\begin{array}{r}-0.26^{\mathrm{d}} \pm 0.09 \\
1.14^{\mathrm{a}} \pm 0.09 \\
0.58^{\mathrm{b}} \pm 0.09 \\
0.06^{\mathrm{c}} \pm 0.09\end{array}$ & $225 \pm 2$ & $\begin{array}{r}-0.06^{\mathrm{c}} \pm 0.08 \\
0.33^{\mathrm{b}} \pm 0.09 \\
0.79^{\mathrm{a}} \pm 0.09 \\
0.11^{\mathrm{b}} \pm 0.08\end{array}$ \\
\hline Mean & $252 \pm 1$ & $0.38 \pm 0.05$ & $240 \pm 1$ & $0.29 \pm 0.04$ \\
\hline
\end{tabular}

1 cycle is an interval of time required for livestock to graze each paddock in a rotation cell before being returned to the paddock originally grazed.

2Oply three of the ten paddocks were grazed before the study was terminated. -bod Means in the same year and column with the same superscript are not different $(P>.05)$ according to the Proc GLM and SAS procedure.

schedule of 1981 produced a narrower range of gray tobosa standing crop, 125 to $561 \mathrm{~kg} / \mathrm{ha}$, compared to a range of 132 to 1,806 $\mathrm{kg} / \mathrm{ha}$ produced by the rigid schedule of 1980 . Brown tobosa standing crop, on the other hand, did not differ $(P>.05)$ among the 10 paddocks either year, but averaged $19 \pm 5 \mathrm{~kg} / \mathrm{ha}$ and $220 \pm 38$ $\mathrm{kg} / \mathrm{ha}$ in 1980 and 1981 , respectively. Green tobosa standing crop differed among the 10 paddocks in 1980 but was similar among them in 1981 (Table 4).

\section{Standing Crop-Quallty}

Treatments did not $(P>.05)$ influence tobosa dry matter, ash, and crude protein between years. Based on the pooled 1980-1981 data the least square means for the crude protein concentration of the green, brown, and gray components were $8.4,6.0$, and $4.7 \%$, respectively; all were significantly different $(P<.05)$. The ash content of tobosa clipped in $1980(12.7 \%)$ was higher $(P<.05)$ than that clipped in $1981(10.7 \%)$. This same trend was found for crude protein in which the $6.7 \%$ recorded in 1980 was significantly $(P<.01)$ higher than the $5.5 \%$ recorded in 1981 . Green tobosa had the lowest $(P<.05)$ dry matter $(93.3 \%)$ content of the total and 3 tobosa standing crop components evaluated.

\section{Helfer Liveweight}

In both 1980 and 1981 the mean initial liveweight of the heifers in the continuously stocked paddock exceeded those in the cell by 27 and $3 \mathrm{~kg}$, respectively (Table 5). At the termination of the 168-day study in 1980, the continuously stocked and rotation cell produced 12 and $7 \mathrm{~kg} / \mathrm{ha}$, respectively. In 1981, after 107 days, the continuously stocked and rotation cell produced 37 and $28 \mathrm{~kg} / \mathrm{ha}$, respectively. In both 1980 and 1981 , the continuously stocked paddock produced more liveweight than did the cell by 5 and $9 \mathrm{~kg} / \mathrm{ha}$, respectively.

Heifer ADG.was less in 1980 than in 1981 (Table 5). The grazing treatments only approached a significant difference $(P=.0627)$ in 1980 and did not differ $(P>.05)$ in 1981. In 1980 ADG was high in cycle one, while in 1981, ADG peaked during cycles 2 and 3 with weight loss recorded in cycle one and very low ADG in cycle 4 (Table 5). Cycle 4 in 1981 differed from the other cycles because only 3 of the 10 paddocks in the cell were grazed.

\section{Conclusions}

Extrapolation of these data into grazing management principles is limited because of the confounding of several factors, including precipitation and management between 1980 and 1981 . However, future studies involving grazing strategy research should consider the implications reported from this study.

Tobosa management should be keyed to the green and brown standing crop (present year's production) not gray tobosa. Therefore, clipping plots to determine total standing crop provides limited information to the range nutritionist. In both 1980 and 1981 , the paddock which was managed under continuous stocking received more precipitation than the 10-paddock cell approximately $0.8 \mathrm{~km}$ to the north. Except for $222 \mathrm{~kg} /$ ha more brown tobosa clipped in the continuously stocked paddock than in the cell in 1981, the green and brown tobosa did not reflect the precipitation difference between the 2 grazing treatments.

Distance from water in the 2 grazing treatments had relatively little influence on the tobosa standing crop during 1980 and 1981. However, in 1980, there was 1.7 times more gray tobosa clipped near the water than at the paddock perimeter in the continuously stocked paddock, and twice as much green tobosa was clipped at the perimeter of the 10-paddock cell in 1981 than in the areas near the $\mathbf{2}$ water sources. Rotating animals on a fixed number of days of grazing over-utilized some of the green tobosa in the paddocks while others were under-utilized in 1980 . There was less gray tobosa and total tobosa on the cell than on the continuous paddock in 1981. Flexible rotation got rid of standing dead but at almost double the reduction in production per ha found in $\mathbf{1 9 8 0 .}$

Precipitation was concentrated between 7 and 27 September 1980 and 1 and 19 August 1981. Based on this precipitation pattern, the majority of the standing crop remaining at the end of 1981 would have been physiologically older than that remaining in 1980 . This may partially explain the negative relationship between precipitation received and crude protein content of the tobosa standing crop in 1980 and 1981. Because the total clipped tobosa in both years averaged $>50 \%$ gray, the total clipping did not reflect the green component as closely as it did the gray component. Sensitivity of the standing crop to the current year's precipitation and management is, therefore, best monitored by partitioning the standing crop into green, brown, and gray. These color components are based on the physiological age of the plant tissue. Because green tobosa has the highest crude protein, and crude protein is a good indicator of forage quality (Sell et al. 1959, Heitschmidt et al. 1982), this is the component to monitor when evaluating grazing management.

Heifer liveweight was dynamic within years and did not show a similar response during the two years. However, in both years, the continuously stocked paddock produced more total liveweight per unit area than did the 10-paddock cell.

Data collection is continuing on these study sites as effective precipitation permits. Future research on both continuous and rotation grazing strategies at this location and others will provide further insight into the principles underlying grazing management. 
Data collection is continuing on these study sites as effective precipitation permits. Future research on both continuous and rotation grazing strategies at this location and others will provide further insight into the principles underlying grazing management.

\section{Literature Cited}

Anderson, D.M. 1981. Manipulating rangeland forage quality with the grazing animal, p. 313-328. In: J.L. Wheeler, and R.D. Mochrie (eds.), Forage evaluation-concepts and techniques. CSIRO. Melbourne, Australia.

Association of Omeial Agricultural Chemists. 1970. Official methods of analysis. (1 lth ed.) Ass. Off. Agr. Chem., Washington, D.C.

Beaty, E.R., G.V. Calvert, and J.E. Engel. 1982. Forage good enough for cattle production: When! J. Range Manage. 35:133-134.

Heitschmidt, R.K., R.A. Gordon, and J.S. Bluntzer. 1982. Short duration grazing at the Texas Experimental Range: Effects on forage quality. $J$. Range Manage. 35:372-374.

Herbel, C.H., and A.B. Nelson. 1974. Utilizing tobosa (Hilaria mutica [Buckl.] Benth.) during the winter and summer. Proc. 12th Inter. Grassl. Cong. III: 184-190. Moscow.
Kucera, C.L., and J.H. Ehrenreich. 1962. Some effects of annual burning on central Missouri prairie. Ecology 43:334-336.

MeNaughton, S.J. 1984. Grazing lawns: Animals in herds, plant form, and coevolution. Amer. Natur. 124:863-886.

Nelson, A.B., C.H. Herbel, and H.M. Jackson. 1970. Chemical composition of forage species grazed by cattle on an arid New Mexico range. N. Mex. State Univ., Agr. Exp. Sta. Bull. 561.

Paulaen, H.A., Jr., and F.N. Ares. 1962. Grazing values and management of black grama and tobosa grasslands and associated shrub ranges of the southwest. USDA Tech. Bull. 1270.

Savory, A. 1978. A holistic approach to ranch management using short duration grazing, p. 555-557. In: Proc. First Inter. Range Cong., Soc. Range Manage. Denver, Colo.

Sell, O.E., J.T. Reid, P.O. Woolfolk, and R.E. Williams. 1959. Intersociety forage evaluation symposium. Agron. J. 51:212-245.

Satistical Analysis System Insttute. 1979. SAS user's guide. SAS Institute, Inc. Raleigh, North Carolina.

Toloumbaye, T. 1982. Utilization of standing crop by cattle under seasonal short duration grazing and seasonal continuous grazing on a semidesert tobosa rangeland. M.S. Thesis, N. Mexico State Univ. 